\title{
Leadership Typology of Traditional Islamic Boarding School in Eastern Indonesia: Learning to Lead from DDI Mangkoso
}

\author{
Ismail Suardi Wekke, Ngesti Wihayuningtyas, Payiz Zawahir Muntaha, \\ Mukhlis Mukhlis
}

\author{
Sekolab Tinggi Agama Islam Negeri (STAIN) Sorong, Indonesia; \\ Sekolab Tinggi Agama Islam Negeri (STAIN) Sorong, Indonesia; \\ Universitas Indonesia, Indonesia; \\ STAI Hubbul Wathan, Duri, Indonesia. \\ ismail@stain-sorong.ac.id, ngestiwihayu@gmail.com, faizzawabir19@gmail.com, \\ mukhlis_ilmi@yahoo.com
}

\begin{abstract}
This article aims to analyses the leadership style of Muslim priest (kyai) in traditional Islamic boarding school (pesantren) seeing from Weber's leadership theory in managing buman resources, infrastructure, finance, and social capital in the pesantren for development. This research also intends to review the existence of selected traditional Islamic boarding school with the types of what Weber's explain in his article. Using library study in a qualitative approach in nature on several sources, i.e., library books, documents and information on the internet. DDI Mangkoso in South Sulawesi province was selected due to its long history as Islamic institution and their renowned and charismatic and transformative kyai since their early years of establishment. The analysis in this research somehow managed to reveal that the three Weber's patterns type is found in the leadership of kyai in several pesantrens around Indonesia including in DDI Mangkoso. Traditional leadership of DDI Mangkoso's kyai is strongly influenced by the tradition of education in pesantren which respects kyai's position as the leader and the founder of the pesantren. However, charismatic and transformative leadership through Anregurutta K.H. Abdul Rahman Ambo Dalle and KH Farid Wajedi were the two most influence styles among Kyai in DDI Mangkoso until now.
\end{abstract}

Keywords: kyai, leadership, Islamic boarding school, DDI Mangkoso

\begin{abstract}
Abstrak
Artikel ini bertujuan untuk menganalisis gaya kepemimpinan kyai di pesantren tradisional dilihat dari teori kepemimpinan Weber dalam mengelola sumber daya manusia, infrastruktur, keuangan, dan modal sosial dalam menjalankan pesantren. Dan juga untuk meninjau keberadaan sebuab pondok pesantren tradisional yang mana terdapat pola kepemimpinan ideal yang dijelaskan Weber dalam teorinya. Studi pustaka dalam pendekatan kualitatif ini meggunakan beberapa sumber, yakni, bukubuku perpustakaan, dokumen dan informasi di internet. DDI Mangkoso Provinsi Sulawesi Selatan dipilih sebagai objek penelitian karena sejarah panjangnya sebagai lembaga Islam dan terkenal memiliki kyai yang karismatik dan transformatif sejak awal pendiriannya. Penelitian ini berhasil mengungkapkan bahwa tipologi kepemimpinan yang di jelaskan oleb Weber ditemukan dalam kepemimpinan kyai di beberapa pesantren di selurub Indonesia termasuk di DDI Mangkoso. Kepemimpinan kyai DDI Mangkoso sangat dipengarubi oleh tradisi pendidikan di pesantren yang menghormati posisi kyai sebagai pemimpin dan pendiri pesantren. Kepemimpinan yang karismatik dan transformatif tergambarkan melalui Anregurutta K.H. Abdul Rahman Ambo Dalle dan KH Farid Wajedi adalah dua gaya yang paling berpengarub di antara Kyai di DDI Mangkoso.
\end{abstract}

Kata Kunci: Kyai, Kepemimpinan, Pesantren, DDI Mangkoso

Permalink/DOI: http://dx.doi.org/10.18326/infsl3v12i2.331-348 


\section{Introduction}

Indonesia was well known as a home to the largest Muslim population around the world. Around 87.2\% from 202.9 million of its people follow Islam. There are numerous Islamic educational institutions scattered across the archipelago of Indonesia. Islamic boarding school (pesantren) in the context of Islamic education institution has existed since the colonial era, in which the process of spreading motivation and thought (nashrul fikroh) is implemented in the Islamic boarding school. In its development, it is currently divided into two categories, namely traditional Islamic boarding school (salafi) and modern Islamic boarding school (khalafi) (Muhaimin, 2014). From these two categories, both of them can be distinguished from the focus of learning on each school. In traditional pesantren, it concerns with teaching students Islamic education without giving them additional general subjects, such as exact sciences used as learned subjects in modern pesantren. Also, the method of learning is also different. Traditional pesantren applies conservative learning methods such as sorogan, classical.

On the other hand, this kind of method is rarely used in modern pesantren. Besides, traditional pesantren also more focus on carrying out religious activities which are structured and organized (Dhofier, 1980). Dhofier argues that pesantren as a traditional Islamic school not only play as a place to study science, religion, Arabic, fiqh, but it also functions as a stronghold of Muslims as well as the center of the spread of Islamic teachings. This cannot be separated from the active role of the Muslim priests (kyai) (Fauzi, 2012). Meanwhile, modern pesantren more concerns with improving students' skills by adapting the latest practices.

Apart from those differences, the most basic similarity lies in the leadership system of pesantren, in which it is controlled by "kyai" recognized as a teacher in the mosque or as a person who runs the rules. This leadership style which is in the hands of kyai makes pesantren seem to be an inclusive organization since most pesantren especially traditional pesantren feels more comfortable with one-way managerial system (Muslim priests-students). Kyai occupies special position having high social stratum that has full 
authority on policies related to activities in the pesantren. In the development of time, the role of kyai also changes along with the current condition. Nowadays, he not only acts as teacher or leader of school but he also starts entering political policy sphere.

Arief states that most traditional pesantren builds conservative relationships, in which kyai has a major force for the doctrine of religion and life not only to his students but also to his followers (public). Hence, this article identifies the leadership style of Darul Dakwah Walirsyad Islamic boarding school (Rachman, 2014).

The term of kyai in Javanese is used to name something highly respected that is not only for humans but also for objects and animals, such as Kyai Rebo Wage which is the elephant's name in the zoo of Yogyakarta or kyai Plered which is the name of a sword in Yogyakarta. Besides, the term kyai is also used to call an elderly (Muchlifah, 2016). However, the term kyai used in this discussion refers to 'kyai who is the leader of Islamic boarding school (Ziemek, 2006).

The majority of pesantren in Indonesia applies centralized leadership engagement to a kyai. The success or failure of pesantren is strongly influenced by the charisma of the kyai, the leader of the pesantren (Kasful, 2015) Thus; it can be categorized that kyai's leadership pattern in pesantren is individual. Therefore, kyai has a very significant role to develop pesantren. Charisma owned by kyai would be one of the important factors that can make pesantren become successful and prime school (Sari, 2015).

Kyai's leadership in pesantren is an art in managing resources owned by pesantren for development. It encompasses human resources, infrastructure, finance and social capital possessed by pesantren. An effective and efficient use on resources would lead the pesantren to easily achieve its educational goal (Nurcholis, 1998) To facilitate the leadership of kyai in managing pesantren and achieving the goal of education, it is very important to set the standard of operation to manage the educational institution. This is necessary to determine the limits and guidelines for the management and distribution of authority and power to the individuals within pesantren (Robbins, 2010). This is because the distribution of 
authority and power to people involved in a team or organization is urgently needed to ease the achievement of the goal (Yukl, 1998).

\section{DDI Mangkoso: The review}

Indonesia was well known as a home to the largest Muslim population around the world. Around 87.2\% from 202.9 million of its people follow Islam. There are numerous Islamic educational institutions scattered across the archipelago of Indonesia. Over time, most of the country's roughly 25,000 pesantrens have expanded to teach not only faith-based principles but also a standard modern curriculum. Among the few that focus solely on religious studies is MAI that in the end transformed as DDI Mangkoso, which was established in 11 January 1938 in the village of Mangkoso. On the convention of the Ablussunnah Wal-Jamaah Alim Ulama Consultation in South Sulawesi, at Watan Soppeng on 16 Rabiul Awal 1366 H (February 17,1947 ) one of the decisions was the need to establish an Islamic organization engaged in education, propaganda and social welfare for the people to foster Muslim individuals who will later be responsible for the implementation of pure Islamic teachings among Muslims and guarantee the preservation of the patriotic spirit of the people of South Sulawesi who at that time were risking their souls to expel the Dutch colonizers and maintain the independence of the August 17, 1945, proclamation.

The name of the organization that will be formed has been debated in deliberation with the emergence of three names, namely Al-Urwatul Wutsqa, Nasrul Haq and Darud Da'wah Wal-Irsyad which was finally chosen as the name of the institution with the understanding Darud means home / place, Da 'wow, the invitation to enter the house, and Al-Irsyad means that the instructions will be obtained through the process of preaching in a particular area. By going through a democratic process in the Aswaja Islamic scholarship forum in South Sulawesi, Darud Da'wah Wal-Irsyad, abbreviated as DDI, got an agreement at the deliberation forum, which was then also a form of transition and integration of Mangkoso Islamic Madrasah Arabiyah (MAI) which was born in dated 11 January 1938 M. or 20 Dzulqaidah $1357 \mathrm{H}$., based on the results of the deliberations of the 
Branch envoys and MAI teachers from the regions in Sha'ban 1366 H. (1947 AD) which is about five months after the Aswaja Ulema Council Meeting took place all over South Sulawesi.

With this integration, it must also be interpreted as a process in improving the structural and operational forms of Mangkoso MAI from a container that is merely a school organization to become an Islamic social organization that has a vertical and horizontal structure in which the field of motion is beside education. And efforts that are of benefit to the people. Darud Da'wah Wal-Irsyad (DDI) in its growth was different from the prevalence of existing organizations in general, because DDI grew from the grassroots of the community in the countryside, so that the countryside was the strongest base for DDI, and from this village grew into cities. This can be seen in all corners of rural South Sulawesi, Central Sulawesi, Southeast Sulawesi, East Kalimantan, Jambi, Riau, and other regions.

\section{Method}

This study is qualitative research which analyzes library sources which relate to the typology of the leadership of traditional Islamic boarding school based on Weber's leadership theory. Based on the data analysis, this study applies library research used to examine libraries relating to the leadership of DDI Mangkoso. This study was conducted by taking data from research results, library books, documents and information on the internet regarding the topic. Data collection method in this study employs the main technique of documentation of information related to the kyai's leadership of traditional Islamic boarding school inclusively the DDI Mangkoso. The data collected in this study were analyzed qualitatively by taking into account the research objective.

\section{Result and Discussion}

Every organization is engaging in the field of social, economy, art, education, etc. sets an ultimate goal to achieve. Therefore, to reach the goal of the organization, various supporting elements 
including human, common goal, teamwork, and tool which enable the organization to achieve the goal are required. Similarly, in an educational institution, all those components are important elements that can be the starting point of the success of the educational institution. One of the important elements which can activate wheel of the organization is human, specifically the leader of the organization. The existence of leader who organizes, manages and keeps the wheel of the organization becomes thoroughly fundamental since through his leadership, it can build a prime organization or vice versa, including in DDI Mangkoso the specific traditional Pondok pesantren that being the focus of this study. Therefore the section below will be designed to give an overview and brief discussion from this on going study regarding the typology of leadership based on Weber's proposed theory and the proposed of an "ideal" Pondok pesantren that covers weber's ideas of leadership.

\section{Weber's leadership theory: The Kyai of Pesantren}

Leadership is a terminology that has mammoth alike definitions and connotations. A leader may be defined as a personal or by the responsibilities, obligations, as well as the position. Further, leaders' authority somehow can be great or limited. Thus, their legitimacy can rest on moral, rational, or practical foundations. Many researchers in social psychologists disciplines distinguish between "affective" and "instrumental" style of leadership. Affective referring on how leader was maintaining good relations among members, while instrumental deals with the ability in advancing a group performance among objective or task is doing.

In his phenomenon book "Economy and Society," Max Weber (1978) proposed three models of leadership legitimacy regarding of political obligation and why many people should obey them: tradition, charisma, and legal-rational. Max Weber proposed theory even though paved much of the way regardinfg identifying on charisma stylistic leader. However, his theories laid important groundwork for how this study might think about and understand leadership in Indonesian pesantrens, Kyai or might be Ulama which strongly related to wide spreads of charismatic hanky panky stories. 
In the history of Islam in Indonesia, the scholar of Islam (ulama) has an important role in the process of providing Islamic knowledge and education to the ummah. The ulama importantly plays to purify Islam and teach the purity of Islam to the society. The Islamic boarding school has a significant role to build the next generation of ulama and Islamic leadership having the good quality of knowledge and spiritual piety, in which both of them are urgently needed to lead society. The life in pesantren is strongly influenced and determined by the values of the Quran, hadith, ijma' of ulama and also the ritual process exemplified by the leader of the pesantren.

Steenbrink states that in traditional society, a person can become a kyai since he is accepted by society as kyai and people come to seek his advice or send their children to learn to him. To be a kyai, there is no formal standard. However, there are several factors that make a person be a kyai: knowledge, piety, heredity, and the number of students. Moreover, as pointed out earlier, pesantren has been established since the beginning of the spread of Islam in Indonesia identified as the colonial era. At that time, pesantren not only functions to teach religious knowledge but also has a role to motivate students to do resistance and to struggle for independence. Pesantren with its main function still exists until this day, the learning of Kitab Kuning, Arabic, and tahfiz Quran.

Over the times, some aspects of traditional pesantren started to improve by adopting or imitating some general programs or skillbased programs as the Islamic boarding school of DDI Mangkoso. At the beginning of its founding, the students were only taught Kitab Kuning, tahfiz Quran and Arabic. However, Ambo Dalle (1938) had the vision to establish pesantren of DDI Mangkoso. Through such a start, Ambo Dalle took an initiative to collect all Muslim scholars/ kyai in South Sulawesi which was then the community of DDI was directly set up by Ambo Dalle.

Teaching materials in traditional pesantren are based on the Quran, hadith and Kitab Kuning, in which Kitab Kuning becomes an important source used in the learning activities in pesantren. Apart from studying the Quran, hadith and Kitab Kuning, a kyai 
in pesantren also frequently educates students the teachings and practices of Sufi which in the terminology of Islam and Indonesia is known as tariqat. It concerns with teaching students and his congregation to be good and pious and to reach the highest peak in the act of devotion.

In addition, to teach formal religious rituals, kyai should not merely focus on teaching Quran, hadith, and Kitab Kuning but he should also start work on matters relating to an economy, such as teaching students social entrepreneurship, in which this skill would be required by the students when they socialize with society. The leadership in Salafiyah DDI Mangkoso Islamic boarding schools, the perspective of Weber's leadership theory can be divided into three, namely traditional, charismatic, and rational. These three Weber's patterns are found in the leadership of kyai in DDI Mangkoso. Traditional leadership of DDI Mangkoso's kyai is strongly influenced by the tradition of education in pesantren which respects kyai's position as the leader and the owner of pesantren. The tradition in pesantren also encourages students to be modest to the kyai.

From the above description, the pattern of leadership in pesantren based on the perspective of Weber's leadership theory can be divided into three, namely traditional, charismatic, and rational. These three Weber's patterns are found in the leadership of kyai several pesantren around Indonesia including in DDI Mangkoso. Traditional leadership of DDI Mangkoso 's kyai is strongly influenced by the tradition of education in pesantren which respects kyai's position as the leader and the founder of the pesantren Anre Gurutta Ambo Dalle and Farid Wajedi. The tradition of the pesantren also encourages students to be modest to the kyai.

The popularity of this pesantren attracted students not only from southern Sulawesi but also from Kalimantan, Java, and Sumatra. The charisma of Anre Gurutta Ambo Dalle made the pesantren become famous with its phenomenon stories of miracle or karomah. The Pesantren of DDI Mangkoso also become more recognized since it made some breakthrough when it was led by Farid Wajedi. Kyai from the alumnus of Al Azhar in Egypt incorporated values and methods of learning in $\mathrm{Al}$ Azhar at the Islamic boarding school of 
DDI. To increase the quality of the pesantren, Farid communicated with various parties, in which one of them was the local government. Started from that stage, DDI Mangkoso transformed into a semimodern Islamic boarding school as the local government began to provide school's facilities such as IT and allocation fund for the school. Up to know, Islamic boarding school of DDI Mangkoso already has educational institutions from elementary to university level. Muhaemin (2014) concludes that the Islamic boarding school of DDI Mangkoso has two leadership styles of Kyai Ambo Dalle and Farid Wajedi, namely charismatic and transformative leadership.

Different from the previous pesantren, Ma'had Ulum Diniyah in Dayah, Aceh has other leadership styles that are consultative participative leadership and instructional leadership used to manage the school. Usman conveys that the leader of Dayah Islamic boarding school has good communication skill. This leadership characteristic can be seen from the leader respecting the opinion of employees to make the decision, providing direction, arousing employees' motivation and building team work which enables all employees to take part in the entire work together. Meanwhile, instructional style is used by the leader of Dayah Islamic boarding school to implement and apply rules of the school to the employees.

Ferry concerns with two styles of kyai's leadership. In his finding, kyai of Islamic boarding school has the religious and charismatic style of leadership. Through religious leadership, kyai not simply teaches religion, but he also becomes the heir and guard of Islamic teachings persistence not only in the internal level of pesantren but also in the level of his followers (society). Furthermore, through the charismatic style of kyai who is also the leader of society, it could act as mediator, advisor or solver towards problems that might occur in society.

\section{Typology of Leadership: Charismatic and Transformative in DDI Mangkoso}

Kyai's leadership in many pesantren in Indonesia including DDI Mangkoso comes from combination between tradition of Islamic education and charisma that is inherited genealogically or is 
kyai's leadership character (Sukamto, 1999) Charismatic leadership has strong persuasion in instilling ideology (Romas, Chumaidi Syarif, 2003) Charismatic leader can be genealogically inherited which can be recognized through big bodies, loud voices, sharp eyes and genealogical bond with previous charismatic kyai as well as engineering process (Rozaki, Abdur, 2004) From some pictures of leadership styles and the run of leadership in Indonesia, it can be stated that each pesantren has a different leadership style. Although some pesantren have similar leadership styles, they still have distinctive features which differentiate one pesantren to another. This is certainly adjusted to the needs of each pesantren. In the case of DDI Mangkoso each typology of weber's leadership can be easily found in this pesantren. However two of the most recognizable were the charisma and the transformative style.

Based on the above document analysis, it can be noticed that four of the five documents this study found in DDI Mangkoso (D-23, D-12, D-27, F-11, T-12) have shown the founder of DDI Mangkoso, Anregurutta K.H. Abdul Rahman Ambo Dalle was revealed as charismatic leadership style in running his Islamic boarding school. He positions himself to listen, to solve problems, to motivate, and to plan future goals, however, the charisma seems to influence the schooling system in DDI Mangkoso a lot. This kind of leadership style emphasizes personal aura that makes ease the owner to manage everything. This type of leadership somehow strengthening two-way communication so that it can ease him to carry out moral education to the students or to build character of the society. Kyai's leadership in traditional pesantren is very close to the concept of karamah and barakah owned by the kyai, in which this makes him be very respected by the students and societies this some how happen to Anregurutta K.H. Abdul Rahman Ambo Dalle.

Charismatic leadership pattern in pesantren was ever reviewed by Turner who concluded that kyai's leadership pattern in pesantren has similarity with charismatic leadership style of the pastor in Christian church (Bryan S. Turner, 1974) Charisma of the kyai is closely related to his religious rituals and habits in his social environment. Such charisma grows naturally and cannot be faked (Sukamto, 1999) In the dynamics of leadership and science, a kiai 
is often recognized having the concept of laduni science. Laduni is the science which is directly given by God to the heart of kyai or recipient without firstly conventionally learning (Trimingham, 1971) The science of laduni, karomah, and barakah is a blessing from the process of riyadhoh performed by the kyai. All those gifts from God are parts of deeds and daily activities done by the kyai, such as being simple to live, preserving good behavior and speech, and always guarding himself against prohibited sin (Hermawan Sulistyo, 1986)

Implication of charismatic leadership on students' religious thought is that they can be more fanatic since they are motivated by emotional connection (batiniyyah) to the kyai. It happens due to students assume that kyai is the best exemplary portrait in practicing Islam perfectly. They will be more certain and obedient to follow the footstep of kyai's spirituality if kyai has "karomab" or strength not possessed by others, for example, kyai can heal sick people by praying to God or he can read the sign of person (Sahal, Akhmad dan Aziz, Munawir, 2015)

Avolio \& Howell describe two prerequisites of the charismatic figure, namely having an ideal nature that is upheld and an ability which is difficult to achieve or defend by a group of people (in the same culture). In the tradition of pesantren, the influence of kyai's charisma lies in the belief of his followers that the kyai has transcendental attributes, such as being a perfect model for the universe and being a living model of ma'rifat (Avolio, B.J., and Howell, J.M, 1992).

Through this kind of leadership style, a kyai will let down his ego and his position as the main leader because he must be a facilitator and take part to work together with his subordinators or his students. Besides, through this kind of style, it would also enable traditional Islamic boarding school to develop and to compete with modern Islamic boarding school which began to appear. Regeneration of kyai's leadership in pesantren is close and hereditary (Dawam Rahardjo,1985).

In addition to charismatic, almost all Islamic boarding schools implement religious - paternalistic leadership. It is kind of leadership 
style that all goals, performances, and all aspects are done through approach of the Prophet SAW oriented to the divinity. This becomes commonplace since pesantren is indeed established for Islamic religious education which aims to make Islam as a worldview of its adherents. However, few people combine this religious leadership with paternalistic leadership which simply can be said fatherly leadership (Nur A., 2014), in which a kyai feel obliged to protect students and staff, to educate them, to not give the opportunity to initiate so that students or subordinates do not have space to do creations. Kyai's charismatic leadership in leading pesantren has the similar essence to the leadership in the social and political territory (Choi, J. 2006).

Kyai who employs instructional style usually more concerns with the application of rule Also, the perspective of some traditional kyai who still consider themselves as the "main force" in pesantren enables this style to keep being applied outside the context of the application of school rules. For example, in daily life, every single word of kyai means the command which must be implemented by students. In pesantren, especially in traditional pesantren, the process to transfer the ideology of Islamic thought from kyai to students is enormously important to preserve ideological typology which he believes in. This can be recognized through how students and graduates of traditional pesantren completely believe in the truth of kyai's religious ideology/thought (Zainal A., 2015)

After analyzing the leadership types of traditional Islamic boarding schools including in DDI Mangkoso, the writer argues that traditional Islamic boarding school such as DDI Mangkoso which started developing its education pattern should be able to combine several existing leadership styles so that it could positively change the school and somehow this is still on and on in DDI Mangkoso. This is carried out since if the Islamic boarding school remains the classical condition of "conservative", they will be left by its devotees. Realizing the changing paradigm of education, KH Farid Wajedi. He made some transformation in many parts of the pesantren, which put him to recognize community needs that can be facilitated by the Islamic boarding school (DDI Mangkoso), Thus, in which he began 
to develop the school-based needs and in the end recommended by many circles. It is also known transformative leadership approach in leadership terminology of pesantren (Bass, B.M., \& Avolio, B.J., 1994) This kind of leadership approach is exemplified by KH Farid Wajedi, the leader of DDI Mangkoso boarding school who has implemented this leadership pattern to improve the quality of school which he leads. This pattern is quite similar to charismatic leadership pattern, in which both patterns emphasize leaders which mean kyai to be a good example for the society. Thus, through such an action, it could drive society to believe in the decision and personal of the kyai. In the pattern of transformative leadership, it is required a system of equal authority among each person in the organization (Evans, M.G.,1970) As in business or social concern, high commitment to accomplish goals of the organization is an absolute condition to ease the achievement of the goal (Sung-gun, 2014)

In transformative leadership management, each person is demanded to have a high sense of responsibility (Blair, D., \& Lunenburg, F. C., 2002). In the environment around pesantren, the practice of responsibility is represented by kyai as the leader of pesantren, and it is firmly held by all ustadz as the teacher in the pesantren. This is because responsibility to build prime Islamic boarding school and to produce good quality of alumnus is a common obligation (Reza K. \& Marzieh G., 2014). Transformative leadership patterns have four dimensions, namely 1). Individualized Consideration. 2). Intellectual Stimulation. 3). Inspirational Motivation and 4). Charismatic Leadership or Idealized Influence (Munevver O.C. \& F. Sehkar F.K., 2015).

The next part of the question is what kind of leadership style that can elaborate some of the above leadership? In some theories, it has been mentioned that the whole theory of leadership has its plus and minus values. However, in the present development, it has emerged a new theory that raises all the values of each leadership style, namely transformational leadership. By using this leadership style, an Islamic boarding school would successfully develop. 


\section{Conclusion}

The analysis in this research somehow managed to reveal that the three Weber's patterns type is found in the leadership of kyai in several pesantrens around Indonesia including in DDI Mangkoso. Traditional leadership of DDI Mangkoso's kyai is strongly influenced by the tradition of education in pesantren which respects kyai's position as the leader and the founder of the pesantren. However, charismatic y Dalle and KH Farid Wajedi were two most influence styles among Kyai in DDI Mstinging following the s. The leaders of Islamic boarding school/kyai not only employ an instructional approach to their students or subordinates but they have also started opening two-way communication to achieve the goal of the school and also to solve problems. The leadership style suitably one of the current Kyai. It seems the charismatic style of leadership since the era of Anregurutta K.H. Abdul Rahman Ambo Dalle shifting into transformative stylistic following $\mathrm{KH}$ Farid Wajedi's type of leadership. It seems the leadership style of Islamic boarding school in DDI Mangkoso is changing following the leadership style. The leadership stylistic of Islamic boarding school/kyai shifting from based charismatic conservative into more transformative and this makes DDI Mangkoso as an "Ideal" place to study Islam in a modern era.

\section{References}

Rozaki, Abdur. 2004. Menabur kharisma menuai kuasa: kiprah kiai dan blatersebagai rezim kembar di Madura. Pustaka Marwa,

Arifin, Achmad Zainal. 2009. "Transmitting Charisma: Re-reading Weber through the Traditional Islamic Leader in Modern Java.

Akhmad Sahal dan Aziz, Munawir (ed.). 2015. Islam Nusantara dari Ushul Fiqh hingga Paham Kebangsaan. Bandung: Mizan. P. 181

Rachman, Arief Aulia. 2014. The Impact of Authoritarian Leadership in Pesantren. Religió: Jurnal Studi Agama-agama Volume 4, Nomor 1. 
Howell, Jane M., and Bruce J. Avolio. 1992. The ethics of charismatic leadership: submission or liberation?. Academy of Management Perspectives 6.2 43-54.

Azyumardi Azra, Islamic Education: Tradition and Modernity toward New Millennium. Jakarta: Logos, 2000, p. 107.

Bass, B.M., \& Avolio, B.J. 1994. Improving organizational effectiveness through transformational leadership. Thousand Oaks, CA: Sage.

Blair, D., \& Lunenburg, F. C. 2002. Transformational leadership, school ratings, and principals' time spent on instructional leadership and management tasks. Paper presented at the annual meeting of the National Council of Professors of Educational Administration.

Bryan S. Turner, Weber, and Islam. 1995. : a critical study, International library of sociology. London; Boston: Routledge \& Kegan Paul, 1974. 23-28..

Bycio, P., Hackett, R. D., \& Allen, J. S. Further assessments of Bass's. 1985.Conceptualization of transactional and transformational leadership. Journal of Applied Psychology, 80, 468-78.

Chumaidi Syarif Romas. Kekerasan di Kerajaan Surgawi, 2003. Yogyakarta: Kreasi Wacana.p.205

Dawam Rahardjo. Pesantren dan Pembaharuan. Jakarta: 1985. LP3ES. P. 46-47

Evans, M.G. 1970. The effects of supervisory behavior on the path-goal relationship. Organizational Behavior and Human Performance, 5, 227-298.

Ferry Muhammadsyah Siregar and Friends. 2013. Religious Leader And Charismatic Leadership In Indonesia: The Role Of Kyai In Pesantren In Java, Kawistara 140 Volume 3 No. 2, 17 (117226)

Gary Yukl, 1998. Leadership in organizations. New Jersey: Englewood Cliffs, , p. 371. 
Hermawan Sulistyo. 1986. Transformasi Kepemimpinan di Pesantren [Leadership Transformation at Pesantren, Pesantren 3, no. 1

Hiroko Horikoshi. 1987. Kiai dan Perubahan Sosial,(terj.) oleh Umar Basalim dan Andi Muarly Sunrawa, Jakarta: P3M.p.226-227

J. Spencer Trimingham, The Sufi Orders in Islam. Oxford: Clarendon Press,1971. 304.

Jaepil Choi. A Motivational Theory of Charismatic Leadership: Envisioning, Empathy, and Empowerment. Journal of Leadership E Organizational Studies. 200613 (1): 2443.

Karel A Steenbrink. 1986. Pesantren Madrasah Sekolah Pendidikan Islam dalam Kurun Modern, Jakarta: LP3ES.:109-110.

Kasful Anawar US. 2015. The Leadership kyai in Islamic boarding school (a study in islamic boarding school in Jambi). Al-Ta lim Jurnal. Vol 22 no 1, , p 88-95

M. Ihsan Dacholfany, Leadership Style in Character Education at The Darussalam Gontor Islamic Boarding. Al-Ulum. Volume 15 Number 2 December 2015

Manfred Ziemek. 2002. Pesantren Dalam Perubahan Sosial. Terjemahan Butche B Sanjoyo. Jakarta: LP3EM.

Muhaemin. 2014. The Mode of Leadership in a Traditional Islamic Boarding School, JICSA Volume 03- Number 01

Munevver Olcum Cetin dan F. Sehkar Fayda Kinik. 2015. An analysis of academic leadership behavior from the perspective of transformational leadership. Procedia - Social and Behavioral Sciences 207. $519-527$

Nasir Usman, dkk. 2016. The Influence Of Leadership In Improving Personnel Performance At Traditional Islamic Boarding School (Dayah), Jurnal Ilmiah Peuradeun Vol. 4 No 2.

Nur Aedi. 2014. Leadership Succession In Pesantren . Jurnal Pendidikan Islam Vol. 1, No. 2, M/1436 H 
Nur Khusniyah Indrawati. Management by Inspiration: Implementation of Transformational Leadership on Business at Pondok Pesantren Sunan Drajat. Procedia - Social and Behavioral Sciences 115 (2014) 79 - 90

Nurcholis Majid. 1998. Bilik-bilik Pesantren: Sebuah Potert Perjalanan. Jakarta: Paramadina, , p . 59.

P. Tim Robbins. 1996. Organizational Behavior(5 -h.ed ). New Jersey: Prentice-Hall, p. 226.

Reza Khany dan Marzieh Ghoreishi. 2014. One the Relationship between Teachers' Sense of Responsibility and Transformational Leadership Style. Jurnal Procedia - Social and Behavioral Sciences $136302-307$

Rohmaniyah, Inayah dan Woodward, Mark. 2012. "Wahhabism, Identity and Secular Ritual: Graduation at an Indonesian High School," al-Jami'ah Journal of Islamic Studies UIN Sunan Kalijaga Yogyakarta, Vol.50, No.1: 123.

Samsul Munir Amin. 2008. Karomah para kiai, Cet. 1. ed. Yogyakarta: Pustaka Pesantren: Distribusi, LKiS Pelangi Aksara,

Sari Hernawati. 2015. The Kiai's Moderat Leadership Model in Improving The Quality Of Educational Services. Jurnal Tawasut Volume 3, Number 1, P 1-24

Siti Muflichah. 2014. The Charisma Leadership Style of Kyai Haji Arwani Amin The founder of Yabuul Quran Pesantren, Kudus JICSA Volume 03- Number 01,p-70

Sukamto. 1999. Kepemimpinan Kyai Dalam Pesantren Kyai's Leadership at Pesantren, Jakarta: LP3ES,

Sung-gunKim, Joongwha. 2014. IntegrationStrategy, Transformational Leadership and Organozational Commitment in Korea's Corporate Split - off. Procedia - Social and Behavioral Sciences 1091353 - 1364.

Weber, M. 1978. Economy and Society: An Outline of Interpretive Sociology. G. Roth,\& C. 
Wittich (Eds.). Berkeley: University of California Press.

Zainal Arifin. 2015. Kepemimpinan Kiai Dalam Ideologisasi Pemikiran Santri Di Pesantren-Pesantren Salafiyah Mlangi Yogyakarta. Jurnal Inferensi, Jurnal Penelitian Sosial Keagamaan Vol. 9, No. 2, 351-372.

Zamakhsyari Dhofier. 1980. The Pesantren Tradition: A Study Of The Role Of The Kyai In The Maintenance of The Traditional Ideology of Islam In Java, Canberra: The Australian National University. 